\section{Pengembangan Lembar Kerja Peserta Didik Berbasis Inkuiri Terbimbing pada Materi Sistem Pencernaan Kelas XI SMA}

\author{
Asriani Askar \\ Firdaus Daud \\ Syamsiah
}

\begin{abstract}
Abstrak. Penelitian ini bertujuan untuk menghasilkan Lembar Kerja Peserta Didik (Student Worksheet) berbasis Guided Enquiry pada materi Sistem Pencernaan untuk kelas XI SMA yang valid dan praktis. Jenis penelitian ini adalah penelitian dan pengembangan $(R \& D)$. Pengembangan lembar kerja Peserta Didik ini menggunakan model ADDIE. Tahapan ADDIE adalah Menganalisis, Merancang, Mengembangkan, Menerapkan, dan Mengevaluasi. Evaluasi lembar kerja siswa ini dievaluasi oleh dua validator ahli. Produk validitas inkuiri terbimbing berdasarkan lembar kerja siswa diperoleh dari validator ahli dengan skor validitas 4,11 (valid). Kepraktisan produk diperoleh dari respons guru dengan skor kepraktisan 89,75 (sangat praktis) dan respons siswa dengan skor kepraktisan 86,0075 (sangat praktis). Berdasarkan hasil penelitian, dapat disimpulkan bahwa pengembangan LK berbasis bahan ajar siswa pada materi Sistem Pencernaan kelas XI SMA valid dan praktis.

Kata kunci: lembar kerja siswa, inkuiri terbimbing, valid, praktis.
\end{abstract}

\section{Pendahuluan}

Kurikulum 2013 merupakan kurikulum yang digunakan setelah Kurikulum Tingkat Satuan Pendidikan (KTSP). Pembelajaran pada kurikulum 2013 lebih menekankan pada pendekatan saintifik, yaitu kegiatan mengamati, menanya, mengumpulkan informasi, mengasosiasi dan mengkomunikasikan. Selain itu pembelajaran juga mengarah pada peningkatan aspek pengetahuan, sikap dan keterampilan (Kemendikbud, 2013). Pelajaran yang menggunakan pendekatan saintifik salah satunya adalah biologi. Biologi merupakan ilmu yang mengkaji tentang makhluk hidup dan kehidupan. Biologi dikatakan sebagai ilmu karena memiliki syarat-syarat ilmu yang salah satunya adalah memiliki proses dan metode ilmiah. Proses dan metode ilmiah digunakan untuk mengembangkan, menemukan pengetahuan serta menerapkannya pada proses pembelajaran biologi (Fatmasary \& Supriyanto, 2015). Pembelajaran biologi tidak hanya mengkaji atau menghapal mengenai konsep, fakta ataupun prinsip-prinsip, tetapi juga proses penemuan informasi. Pembelajaran dengan proses penemuan akan lebih bermakna dan mudah diingat dibanding hanya dengan cara menghapal. Karakteristik pembelajaran biologi adalah mengkaji proses kehidupan nyata di lingkungan. Selain itu kemampuan bereksperimen dan mengobservasi lingkungan sangat penting dalam mempelajari biologi agar lingkungan

\section{Biology Teaching \\ and Learning}

p-ISSN 2621 - 5527

e-ISSN 2621 - 5535

Abstract. This research is aimed to produce a Student Worksheet based Guided Inquiry on Digestive System material for class XI senior high school that is valid and practical. The type of this research is research and development $(R \& D)$. The development of this student worksheet used ADDIE models. The stages of ADDIE are Analyze, Design, Develop, Implement and Evaluate. The evaluation of this student worksheet is evaluated by two expert validators. The validity product

of student worksheet based guided inquiry is obtained from expert validators with a validity score of 4,11 (valid). The practicality of the product is obtained from teachers response with a practicality score of 89.75 (very practical) and students response with a practicality score of 86.0075 (very practical). Based on the results, it can be concluded that the development of student worksheet based Guided Inquiry on Digestive System material for class $X I$ senior high school is valid and practical.

Keywords: Student worksheet, Guided Inquiry, Valid, Practical.

Asriani Askar

Universitas Negeri Makassar Indonesia

Firdaus Daud

Universitas Negeri Makassar Indonesia

Syamsiah

Universitas Negeri Makassar Indonesia 
dapat tereksplorasi. Guru merupakan salah satu subjek yang berperan penting dalam pelaksanaan pembelajaran terlebih lagi dalam kurikulum 2013. Peran guru diantaranya dituntut untuk menyusun dan mengembangkan perangkat pembelajaran. Perangkat pembelajaran merupakan pegangan dan pedoman guru dalam melaksanakan pembelajaran. Apabila diterapkan dengan baik maka pembelajaran dapat berjalan lancar dan mampu mengaktifkan peserta didik.

Lembar Kerja Peserta Didik (LKPD) merupakan salah satu perangkat pembelajaran yang harus dimiliki dan dikembangkan oleh guru. LKPD yang berupa lembar-lembaran digunakan untuk membantu peserta didik dalam pembelajaran. Pedoman Umum Pengembangan Bahan Ajar yang disusun oleh Depdiknas (2008) menyatakan bahwa LKPD adalah Lembar Kerja Peserta Didik (student worksheet) yang merupakan lembaran-lembaran berisi tugas yang harus dikerjakan oleh peserta didik. Lembar kerja tersebut biasanya dapat berupa petunjuk atau langkah-langkah kerja untuk menyelesaikan tugas.

Perhatian pemerintah di bidang pendidikan diantaranya dengan adanya perubahan kurikulum untuk memperbaiki kualitas pendidikan dan sumber daya manusia. Berdasarkan Permendikbud Nomor 65 tahun 2013 tentang Standar Proses, mengatakan bahwa untuk memperkuat pendekatan ilmiah (scientific), tematik terpadu (tematik antarmata pelajaran), dan tematik (dalam suatu mata pelajaran) perlu diterapkan pembelajaran berbasis penyingkapan/penelitian (discovery/inquiry learning). Salah satu strategi pembelajaran yang berbasis penemuan dalam kegiatan pembelajaran, dan memudahkan peserta didik memperoleh pengetahuan serta pemahaman yaitu inkuiri.

Inkuiri adalah salah satu model pembelajaran berasal dari kata inquiry yang merupakan kata dalam bahasa Inggris yang berarti penyelidikan/meminta keterangan; terjemahan bebas untuk konsep ini adalah "siswa diminta mencari dan menemukan sendiri". Dalam konteks penggunaan inkuiri sebagai metode belajar mengajar, siswa ditempatkan sebagai subjek pembelajaran, yang berarti bahwa siswa memiliki andil besar dalam menentukan suasana pembelajaran. Dalam metode ini, setiap peserta didik didorong untuk terlibat aktif dalam proses belajar mengajar (Anam, 2016). Kourilsky dalam Hamalik (2011) juga mengemukakan bahwa pengajaran yang berbasis inkuiri adalah suatu strategi yang berpusat pada siswa di mana kelompok siswa inquiry ke dalam suatu isu atau mencari jawaban-jawaban terhadap isi pertanyaan melalui suatu prosedur yang digariskan secara jelas dan struktural kelompok.

Pembelajaran inkuiri mampu membuat peserta didik belajar secara aktif dan memperoleh pengalaman langsung dengan cara menemukan sendiri konsep-konsep, fakta-fakta maupun prinsip-prinsip materi. Dengan demikian peserta didik akan termotivasi untuk belajar menemukan sendiri dan mencari solusi dari permasalahan yang ada. Sebagaimana dalam penelitian Putri \& Widiyatmoko (2013) pembelajaran biologi sebaiknya dilakukan secara inkuiri ilmiah untuk menumbuhkembangkan kemampuan berpikir, bekerja dan bersikap ilmiah serta mengkomunikasikannya sebagai aspek kecakapan hidup.

Penelitian sebelumnya yang dilakukan oleh Mu'ammaroh (2013), LKPD inkuiri dapat memotivasi belajar dan membantu lebih aktif dalam pembelajaran. LKPD yang dikembangkan memang didesain agar peserta didik belajar dengan melakukan eksperimen dan mampu membangun konsep sendiri. Oleh karena itu dibutuhkan bahan ajar yang dapat membangkitkan minat belajar peserta didik dan dapat berpengaruh positif terhadap hasil belajar peserta didik. LKPD berbasis inkuiri diharapkan mampu membuat peserta didik menemukan konsep, fakta, prinsip dan jawaban dari hal yang belum diketahui melalui percobaan yang dilakukan dan pertanyaan yang memicu tingkat berpikir peserta didik.

Kemampuan sains peserta didik harus terus ditingkatkan dengan membiasakan untuk aktif dalam proses pembelajaran agar keterampilan berpikir peserta didik semakin membaik. Keterampilan tersebut dapat diaktifkan dengan memanfaatkan LKPD berbasis inkuiri terbimbing. Pengembangan LKPD berbasis inkuiri terbimbing perlu diterapkan karena diharapkan peserta didik dapat belajar secara aktif dengan bantuan alat, bahan dan pertanyaan 
yang telah disiapkan guru. Adapun jawaban dari pertanyaan tersebut dapat ditemukan oleh peserta didik melalui proses penyelidikannya. Disini guru hanya sebagai pembimbing dalam hal membangun pengetahuan dan pemahaman peserta didiknya, sehingga ketika ada yang salah konsep dari penyelidikannya, guru yang akan memperbaiki konsepnya kemudian peserta didiknya yang akan menarik kesimpulan sendiri.

Lembar kerja peserta didik dapat digunakan pada materi Sistem Pencernaan. LKPD digunakan untuk mengerjakan tugas. Jadi peserta didik mengerjakan soal-soal secara kelompok berdasarkan pengetahuan awal yang telah diperoleh melalui penyampaian materi dari guru, dengan karakteristik LKPD berbasis inkuiri terbimbing.

Berdasarkan hasil wawancara pada guru dan peserta didik di SMA Negeri 11 Makassar, diketahui bahwa belum adanya penggunaan LKPD berbasis inkuiri terbimbing. Selain itu pembelajaran pada saat praktikum dilakukan belum mengaktifkan peserta didik untuk melakukan percobaan. Akibatnya peserta didik kurang memahami apa alasan dilakukannya praktikum. Sehingga diperlukan model pembelajaran inkuiri terbimbing agar pembelajaran dengan metode praktikum yang terpusat pada peserta didik lebih efektif dalam membimbing peserta didik untuk menemukan sendiri pengetahuannya.

Mengingat pentingnya lembar kerja peserta didik di dalam proses pembelajaran, maka perlu dilakukan pengembangan. Hal inilah yang mendorong peneliti untuk melakukan penelitian yang berjudul "Pengembangan Lembar Kerja Peserta Didik (LKPD) Berbasis Inkuiri Terbimbing pada Materi Sistem Pencernaan Kelas XI SMA".

Berdasarkan latar belakang di atas, maka rumusan masalah yang menjadi permasalahan dalam penelitian ini adalah: (1) Apakah lembar kerja peserta didik (LKPD) berbasis inkuiri terbimbing pada materi sistem pencernaan kelas XI SMA memenuhi kriteria valid? (2) Apakah lembar kegiatan peserta didik (LKPD) berbasis inkuiri terbimbing pada materi sistem pencernaan kelas XI SMA memenuhi kriteria praktis?

Berdasarkan rumusan masalah di atas, maka tujuan penelitian ini adalah: (1) Menghasilkan lembar kerja peserta didik (LKPD) berbasis inkuiri terbimbing pada materi sistem pencernaan kelas XI SMA yang memenuhi kriteria valid. (2) Menghasilkan lembar kerja peserta didik (LKPD) berbasis inkuiri terbimbing pada materi sistem pencernaan kelas XI SMA yang memenuhi kriteria praktis.

\section{Metode Penelitian}

Jenis penelitian yang digunakan adalah Penelitian dan Pengembangan (Research and Development) yakni pengembangan Lembar Kerja Peserta Didik berbasis Inkuiri Terbimbing pada Materi Sistem Pencernaan Kelas XI SMA. Pengembangan LKPD ini menggunakan model ADDIE yaitu dari (1) Analyze (Analisis), (2) Design (Perancangan), (3) Develop (Pengembangan), (4) Implement (Implementasi) dan Evaluate (Evaluasi). Penelitian ini dilaksanakan di SMA Negeri 11 Makassar bulan Juli-Agustus 2019.

Produk yang dikembangkan dinilai oleh dua validator ahli untuk menguji kevalidan produk dan untuk menguji kepraktisan dilakukan dengan melihat penilaian praktisi dalam hal ini guru dan respon peserta didik.

Langkah- langkah kevalidan produk menurut Hobri (2010), melalui proses berikut.

a. Melakukan rekapitulasi data hasil penilaian validitas ke dalam tabel yang meliputi (1) hasil penilaian validator $\left(\mathrm{V}_{\mathrm{ji}}\right),(2)$ kriteria $\left(\mathrm{K}_{\mathrm{i}}\right)$, (3) aspek $\left(\mathrm{A}_{\mathrm{i}}\right)$.

b. Menentukan rata-rata hasil penilaian semua validator untuk setiap kriteria menggunakan rumus:

$$
\overline{\boldsymbol{K}_{i}}=\frac{\sum_{j=1}^{n} \boldsymbol{V}_{j i}}{n}
$$




\section{Keterangan:}

$\overline{K_{i}}$ : rata-rata kriteria ke-i,

$V_{j i}$ : skor hasil penilaian validator ke-j terhadap kriteria ke-i

$n$ : banyaknya validator

c. Menentukan rata-rata tiap aspek menggunakan rumus:

$$
\overline{\boldsymbol{A}_{i}}=\frac{\sum_{j=1}^{n} \overline{\boldsymbol{K}}_{j i}}{n}
$$

Keterangan:

$A_{i}$ : rata-rata aspek ke-i,

$\overline{K_{i}}$ : rata-rata aspek ke-i kriteria ke-j,

$n$ : banyaknya kriteria dalam aspek ke-i

d. Menentukan nilai atau rata-rata total dengan rumus:

$$
V_{a}=\frac{\sum_{j=1}^{n} \bar{A}_{i}}{n}
$$

Keterangan:

$v a$ : rata-rata total,

$A i$ : rata-rata aspek ke-i

$n$ : banyaknya aspek

Adapun menurut Riduwan (2010), untuk menentukan persentase penilaian praktisi, digunakan rumus berikut ini:

$$
\% \overline{\mathrm{R}}=\frac{\overline{\mathrm{R}}}{\mathrm{n}} \times 100 \%
$$

Keterangan:

$\% \overline{\mathrm{R}}$ : persentase nilai rata-rata respon

$\overline{\mathrm{R}}$ : rata-rata nilai respon

n : jumlah responden

\section{Hasil Penelitian}

Hasil dari penelitian ini adalah produk berupa pengembangan Lembar Kerja Peserta Didik (LKPD) biologi berbasis Inkuiri Terbimbing pada materi Sistem Pencernaan yang dibuat untuk memenuhi kriteria valid dan praktis. Adapun hasil analisis uji kevalidan instrument penelitian dan produk sebagai berikut.

\section{Kevalidan LKPD}

Produk pengembangan yaitu LKPD diuji kevalidannya melalui lembar validasi produk oleh 2 validator ahli. Hasil analisis validasi produk yang telah dikembangkan disusun pada Tabel 1. berikut. 
Tabel 1. Analisis Hasil Validasi Produk LKPD

\begin{tabular}{|c|c|c|c|c|}
\hline Aspek yang dinilai & Butiran Aspek & $\bar{K}_{i}$ & $\overline{A_{i}}$ & Ket \\
\hline Identitas LKPD & $\begin{array}{l}1 \\
2\end{array}$ & $\begin{array}{l}4.5 \\
4.5\end{array}$ & 4.5 & Sangat Valid \\
\hline Syarat Teknis & $\begin{array}{l}3 \\
4 \\
5 \\
6\end{array}$ & $\begin{array}{c}3.5 \\
4 \\
4 \\
4\end{array}$ & 3.88 & Valid \\
\hline Syarat Konstruksi & $\begin{array}{l}7 \\
8 \\
9\end{array}$ & $\begin{array}{l}4 \\
4 \\
4\end{array}$ & 4 & Valid \\
\hline Isi & $\begin{array}{l}10 \\
11 \\
12 \\
13\end{array}$ & $\begin{array}{l}4 \\
4 \\
4 \\
4 \\
\end{array}$ & 4 & Valid \\
\hline Kegiatan Inkuiri & $\begin{array}{l}14 \\
15 \\
16 \\
17 \\
18 \\
19\end{array}$ & $\begin{array}{l}4 \\
4 \\
4 \\
4 \\
4 \\
4 \\
\end{array}$ & 4 & Valid \\
\hline Daya Tarik & $\begin{array}{l}20 \\
21\end{array}$ & $\begin{array}{c}4.5 \\
4\end{array}$ & 4.25 & Valid \\
\hline Rata-rata & & & 4.11 & Valid \\
\hline
\end{tabular}

Tabel 1 menunjukkan nilai uji kevalidan terhadap produk penelitian yaitu LKPD ditinjau dari 6 aspek penilaian. Dari ke- 6 aspek tersebut diperoleh nilai kevalidan produk LKPD yaitu 4.11. Berdasarkan data tersebut dapat disimpulkan bahwa produk LKPD dengan rata-rata 4.11 ini dikategorikan valid dengan kriteria kevalidan $3,5 \leq \mathrm{Va}<4,5$.

\section{Kepraktisan LKPD}

Tahapan ini dilakukan untuk mengetahui kepraktisan LKPD hasil pengembangan dari analisis penilaian responden yaitu guru dan peserta didik. Pada tahap ini, produk LKPD yang dikembangkan akan diperlihatkan kepada guru dan peserta didik guna dengan mengamati langsung. Setelah itu, guru dan peserta didik diminta untuk mengisi angket respon berdasarkan apa yang telah diamati pada LKPD. Adapun hasil analisis data dari angket penilaian kepraktisan oleh guru dan peserta didik ialah sebagai berikut.

Tabel 2. Hasil Penilaian Guru terhadap Produk LKPD

\begin{tabular}{|c|c|c|c|}
\hline Aspek & $\mathbf{( \mathbf { R } )}$ & $\mathbf{\%} \mathbf{\mathbf { R }}$ & Kategori \\
\hline Konstruksi Pengetahuan & 4.75 & 95 & Sangat Praktis \\
\hline Desain & 4.33 & 86.67 & Sangat Praktis \\
\hline Bahasa & 4 & 80 & Sangat Praktis \\
\hline Kegiatan Inkuiri Terbimbing & 4.87 & 97.33 & Sangat Praktis \\
\hline Jumlah & 17.95 & 359 & \\
\hline Rata-rata & 4.4875 & 89.75 & Sangat Praktis \\
\hline
\end{tabular}


Tabel 3. Hasil Penilaian Peserta Didik terhadap Produk LKPD

\begin{tabular}{|c|c|c|c|}
\hline Aspek & $\mathbf{( \overline { \mathbf { R } } )}$ & $\mathbf{\%} \overline{\mathbf{R}}$ & Kategori \\
\hline Manfaat & 4.18 & 83.5 & Sangat Praktis \\
\hline Desain & 4.37 & 87.33 & Sangat Praktis \\
\hline Kegiatan Inkuiri Terbimbing & 4.09 & 81.87 & Sangat Praktis \\
\hline Bahasa & 4.57 & 91.33 & Sangat Praktis \\
\hline Jumlah & 17.21 & 344.03 & \\
\hline Rata-rata & 4.3025 & 86.0075 & Sangat Praktis \\
\hline
\end{tabular}

Tabel 2. menunjukkan total nilai kepraktisan LKPD berdasarkan penilaian 3 orang guru yaitu $89.75 \%$. Berdasarkan tabel kriteria kepraktisan produk pengembangan, kriteria tersebut berada pada $80 \leq \mathrm{R} \leq 100$. Dengan kategori tersebut LKPD hasil pengembangan dinyatakan sangat praktis. Dari uji kepraktisan tersebut, responden menyarankan untuk membuat juga tujuan praktikum diluar dari tujuan pembelajaran pada LKPD.

Tabel 3. menunjukkan total nilai kepraktisan LKPD berdasarkan penilaian 30 orang peserta didik yaitu $86.0075 \%$. Berdasarkan tabel kriteria kepraktisan produk pengembangan, kriteria tersebut berada pada $80 \leq \mathrm{R} \leq 100$. Dengan kategori tersebut LKPD hasil pengembangan dinyatakan sangat praktis.

\section{Pembahasan}

Perangkat pembelajaran merupakan hal yang perlu dipersiapkan oleh guru sebelum proses pembelajaran berlangsung. Adanya perangkat pembelajaran yang berkualitas merupakan salah satu faktor penunjang dalam proses pembelajaran agar berjalan dengan baik dan dapat meningkatkan mutu pendidikan (Hala et al., 2017). Salah satu perangkat pembelajaran yang digunakan yaitu LKPD (Lembar Kerja Peserta Didik). LKPD digunakan untuk memudahkan pelaksanaan pengajaran kepada peserta didik.

Hasil wawancara yang telah dilakukan diketahui bahwa belum adanya penggunaan LKPD berbasis inkuiri terbimbing. Selain itu pembelajaran pada saat praktikum dilakukan belum mengaktifkan peserta didik untuk melakukan percobaan. Akibatnya peserta didik kurang memahami apa alasan dilakukannya praktikum.

Berdasarkan hal-hal tersebut, disusun sebuah penyelesaian untuk menghadapi permasalahan tersebut. Penyelesaian yang diberikan oleh peneliti adalah pengembangan LKPD sebagai bahan ajar yang mampu membantu mengaktifkan keterampilan berpikir peserta didik. Dengan demikian penelitian pengembangan LKPD berbasis inkuiri terbimbing pada materi sistem pencernaan kelas XI ini dilakukan. Menurut Sanjaya (2006) inkuiri adalah rangkaian kegiatan pembelajaran yang menekankan proses berpikir dan meningkatkan keterampilan proses sains untuk mencari dan menemukan sendiri jawaban dari suatu masalah yang dipertanyakan. Melalui pembelajaran inkuiri pula menurut Ramlawati et al., (2018), peserta didik dapat merekonstruksi pengetahuan dan implementasinya sehinggadapat meningkatkan keterampilan proses sains. Hal ini seiring dengan tuntutan materi pembelajaran yang tidak hanya tersusun atas hapalan dan pemahaman, tetapi juga tersusun atas materi yang kompleks. Dengan demikian, LKPD berbasis inkuiri diharapkan dapat membantu peserta didik untuk menjadi lebih aktif. Untuk itulah penelitian ini dilaksanakan untuk menghasilkan LKPD yang memenuhi tahap valid dan praktis.

\section{Kevalidan LKPD}

Pengembangan LKPD sebelum digunakan pada uji kepraktisan oleh guru dan peserta didik perlu diuji kevalidan atau kelayakan penggunaannya. Untuk mengetahui kelayakannya maka didesain instrumen penilaian untuk mengukur tingkat kevalidan LKPD yang 
dikembangkan. LKPD dikatakan valid apabila memenuhi kriteria yang telah ditentukan dengan melakukan perbaikan berdasarkan saran-saran yang diberikan oleh validator ahli terhadap aspek-aspek yang dinilai pada LKPD. Aspek-aspek yang dinilai pada produk penelitian yaitu LKPD terdiri atas aspek identitas LKPD, syarat teknis, syarat konstruksi, isi, kegiatan inkuiri terbimbing dan daya tarik. Saat proses validasi LKPD, ada beberapa masukan dan saran dari validator sehingga dilakukan revisi untuk menghasilkan LKPD berbasis inkuiri terbimbing yang valid/layak digunakan.

Ditinjau dari aspek identitas, LKPD dinyatakan sangat valid dengan nilai 4.5. Artinya LKPD yang dikembangkan telah sesuai dengan struktur LKPD secara umum menurut Depdiknas (2008) yaitu terdapat judul dan petunjuk belajar di dalam LKPD. Ditinjau dari aspek syarat teknis dan syarat konstruksi, masing-masing LKPD dinyatakan valid dengan nilai 3.88 dan 4 . Syarat teknis dan konstruksi berkenaan dengan penggunaan bahasa, susunan kalimat, gambar maupun penampilan sehingga dapat dimengerti oleh peserta didik. Hal ini sesuai pendapat Darmodjo \& Kaligis dalam Kusdiningsih (2016) bahwa LKPD akan memberi pengaruh yang cukup besar dalam proses pembelajaran, apabila dalam penyusunan LKPD memenuhi syarat teknis dan syarat konstruksi.

Ditinjau dari aspek isi, LKPD dinyatakan valid dengan nilai 4. Artinya LKPD yang dikembangkan sesuai dengan kurikulum yang berlaku yaitu kurikulum 2013. Hal ini sesuai dengan Depdiknas (2008) menyatakan bahwa bahan ajar yang dikembangkan harus sesuai dengan tuntutan kurikulum. Ditinjau dari aspek kagiatan inkuiri terbimbing, LKPD dinyatakan valid dengan nilai 4. Hal ini membuktikan bahwa LKPD telah memuat fase-fase inkuri terbimbing yaitu mengidentifikasi masalah, merumuskan hipotesis, mengumpulkan data, menguji hipotesis dan menarik kesimpulan. Hal ini sesuai tahapan pembelajaran inkuiri yang di kemukakan oleh Eggen \& Kauchak dalam Trianto (2007) yaitu: menyajikan pertanyaan atau masalah, membuat hipotesis, merancang percobaan, melakukan percobaan untuk mengumpulkan informasi, mengumpulkan dan menganalisis data, serta membuat kesimpulan.

Ditinjau dari aspek daya tarik, LKPD dinyatakan valid dengan nilai 4.25. Aspek daya tarik tersebut memuat warna, layout (tata letak) dan gambar pendukung. Menurut Depdiknas (2008) pemilihan warna background kontras dengan huruf agar tulisan pada bahan ajar cetak mudah dibaca dan pada bagian-bagian khusus digunakan tulisan yang berbeda agar menarik perhatian pembaca.

Analisis hasil validasi produk LKPD menunjukkan bahwa total nilai rata-rata kevalidan untuk semua aspek penilaian yaitu $V_{a}=4,11$. Berdasarkan kategori tingkat kevalidan oleh Hobri (2010) nilai tersebut dikategorikan valid $(3,5 \leq$ Va $<4,5)$. Dari kategori tersebut LKPD tidak perlu direvisi dan layak digunakan oleh guru dan peserta didik untuk uji kepraktisan.

\section{Kepraktisan LKPD}

Uji kepraktisan dilakukan untuk mengetahui kepraktisan produk penelitian. Responden pada uji ini yaitu guru dan peserta didik yang melakukan penilaian pada produk. Penilaian produk pada uji kepraktisan menurut Daud et al., (2015) menggunakan angket respon guru dan peserta didik.

Angket respon guru terdiri atas 4 aspek yaitu aspek konstruksi pengetahuan, desain, bahasa dan aspek kegiatan inkuiri terbimbing. Uji kepraktisan juga dilakukan oleh peserta didik dalam uji coba terbatas sebanyak 30 orang yang telah mempelajari materi sistem pencernaan dari kelas XII MIA 6. Adapun angket respon peserta didik juga terdiri atas 4 aspek yaitu aspek manfaat, desain, kegiatan inkuiri terbimbing dan aspek bahasa.

Ditinjau dari aspek konstruksi pengetahuan, LKPD sangat praktis menurut guru dengan nilai 95\% dan dari aspek manfaat, LKPD sangat praktis menurut peserta didik dengan nilai 83.5\%. Hal ini berarti LKPD dapat memudahkan guru dalam pembelajaran, mengaktifkan peserta didik dan mengkonstruksi pengetahuan peserta didik. Menurut Syarifah (2017) manfaat yang diperoleh dengan menggunakan LKPD yaitu memudahkan guru dalam mengelolah proses 
belajar, mengarahkan peserta didik menemukan konsep-konsep serta mengembangkan keterampilan proses peserta didik.

Ditinjau dari aspek desain, LKPD sangat praktis menurut guru dengan nilai $86.67 \%$ dan peserta didik dengan nilai 87.33\%. Aspek desain ini memuat warna, layout (tata letak) dan gambar relevan. Hal ini sesuai pendapat Suwahru et al., (2018) pemilihan warna dalam pembuatan LKPD ini perlu diperhatikan karena menghasilkan ketertarikan terhadap suatu produk. Ditinjau dari aspek bahasa, LKPD sangat praktis menurut guru dengan nilai $80 \%$ dan peserta didik dengan nilai $91.33 \%$. Komponen bahasa berkenaan dengan penggunaan kalimat yang mudah dipahami, tidak bermakna ganda dan sesuai kaidah Bahasa Indonesia. Menurut Depdiknas (2008) bahan ajar harus memuat kalimat yang jelas dan tidak terlalu panjang.

Ditinjau dari aspek kegiatan inkuiri terbimbing, LKPD sangat praktis menurut guru dengan nilai $97.33 \%$ dan peserta didik dengan nilai $81.87 \%$. dengan penilaian ini bahwa di dalam LKPD telah memuat fase-fase inkuiri terbimbing. Dengan menggunakan inkuiri dapat membuat peserta didik lebih aktif dalam proses penyelidikannya. Hal itu sesuai menurut Pujiati et al., (2016) bahwa model pembelajaran inkuiri merupakan proses bertanya dan mencari tahu jawaban, sehingga tugas besar guru yaitu menstimulus peserta didiknya agar menggunakan kemampuan berpikirnya secara kritis dan logis sehingga menemukan pertanyaan ilmiahnya sendiri lalu kemudian dipecahkan sendiri dengan serangkaian kegiatan inkuiri.

Analisis hasil uji kepraktisan LKPD oleh guru menunjukkan bahwa total nilai rata-rata sebesar $89.75 \%$ yang berarti sangat praktis $(80 \leq \mathrm{R} \leq 100)$. Berdasarkan kategori tersebut LKPD hasil pengembangan dinyatakan sangat praktis bagi guru untuk digunakan dalam pembelajaran. Uji kepraktisan dengan respon guru ini dilakukan oleh 3 orang guru mata pelajaran biologi. Dari uji kepraktisan tersebut, responden menyarankan untuk membuat juga tujuan praktikum diluar dari tujuan pembelajaran pada LKPD.

Analisis hasil uji kepraktisan LKPD oleh peserta didik menunjukkan bahwa total nilai rata-rata sebesar $86.0075 \%$ yang berarti sangat praktis $(80 \leq R \leq 100)$. Berdasarkan kategori tersebut LKPD hasil pengembangan juga dinyatakan sangat praktis oleh peserta didik untuk digunakan dalam proses pembelajaran. Hasil analisis penilaian dilakukan oleh 30 orang peserta didik. Pada uji kepraktisan, peserta didik lebih tertarik dengan tampilan LKPD.

Hasil uji kepraktisan yang telah dilakukan diperoleh kategori sangat praktis untuk kedua responden baik dari guru maupun dari peserta didik. Sehingga dapat dikatakan LKPD berbasis inkuiri terbimbing pada materi sistem pencernaan dapat diterima dengan baik. Hal ini sesuai dengan pendapat Anitah (2010) yang menyatakan bahwa hasil uji kepraktisan yang baik dapat menunjukan bahwa LKPD sebagai sumber belajar yang sengaja dirancang atau resources by design, dapat mengantarkan belajar peserta didik lebih bermakna sehingga mampu mencapai tujuan pembelajaran yang diinginkan.

\section{Kesimpulan}

Berdasarkan hasil penelitian dan pembahasan yang telah diuraikan sebelumnya, maka dapat ditarik beberapa kesimpulan sebagai berikut (1) Lembar Kerja Peserta Didik (LKPD) berbasis inkuiri terbimbing pada materi sistem pencernaan kelas XI SMA yang telah dikembangkan memenuhi kriteria valid berdasarkan penilaian yang dilakukan oleh validator. (2) Lembar Kerja Peserta Didik (LKPD) berbasis inkuiri terbimbing pada materi sistem pencernaan kelas XI SMA yang telah dikembangkan memenuhi kriteria praktis berdasarkan penilaian yang dilakukan oleh responden yaitu guru dan peserta didik.

\section{Referensi}

Anitah, S. (2010). Media Pembelajaran. Surakarta. UNS Press 
Pengembangan Lembar Kerja Peserta Didik Berbasis Inkuiri Terbimbing pada Materi Sistem Pencernaan Kelas XI SMA

Daud, F., \& Rahmadana, A. (2015). Pengembangan Media Pembelajaran Biologi Berbasis Elearning pada Materi Ekskresi Kelas XI IPA 3 SMAN 4 Makassar. Bionature, 16 (1).

Depdiknas. (2008). Panduan Pengembangan Bahan Ajar. Jakarta: Direktorat Pembinaan Sekolah Menengah Atas.

Fatmasary, A., \& Supriyanto. (2015). Pengembangan LKS Praktikum Identifikasi Proses Pencernaan Hewan Ruminansia Berbasis Guided Inquiry di SMA. UNNES Jurnal Bio Edu, 4 (1), 1-8.

Hala, Y., Syafiuddin., \& Danial, M. (2017). Pengembangan Perangkat Pembelajaran Biologi Berbasis Pendekatan Saintifik Peserta Didik MAN Dampang Bantaeng. Bionature, 17(1).

Hobri. (2010). Metodologi Penelitian Pengembangan (Aplikasi pada Penelitian Pendidikan Matematika). Jember. Pena Salsabila.

Kemendikbud. (2013). Peraturan Menteri Pendidikan dan Kebudayaan Republik Indonesia Nomor. 65 tentang Standar Proses Pendidikan Dasar dan Menengah. Jakarta: Kementerian Pendidikan dan Kebudayaan.

Kemendikbud. (2013). Peraturan Menteri Pendidikan dan Kebudayaan Republik Indonesia Nomor. 81 A tentang Implementasi Kurikulum. Jakarta. Kementerian Pendidikan dan Kebudayaan.

Kusdiningsih, E.Z. (2016). Pengembangan LKPD Berbasis Kemampuan Argumentasi dengan Menggunakan Metode Problem Solving untuk Meningkatkan Literasi Sains. Program Pasca Sarjana Magister Keguruan IPA. Universitas Lampung.

Mu'ammaroh, S. (2013). Pengembangan LKS Berbasis Inkuiri Materi Pemerolehan Nutrisi Tumbuhan. Bio Edu UNESA. 2 (3), 175-178.

Pujiati, P., Hala, Y., \& Taiyeb, A. M. (2016). Peningkatan Aktivitas, Motivasi dan Hasil Belajar IPA Biologi Peserta Didik Kelas VIIIA-1 MTsN Watampone melalui Model Pembelajaran Inkuiri Terbimbing. Sainsmat, 5(1).

Putri, B.K., \& A. Widiyatmoko. (2013). Pengembangan LKS IPA Terpadu Berbasis Inkuiri Tema Darah di SMP Negeri 2 Tengaran. Jurnal Pendidikan IPA Indonesia FPMIPA UNNES, 2 (2), 102-106.

Ramlawati, R., Jirana, J., \& Muhiddin, P. (2018). Pengembangan Lembar Kerja Peserta Didik (LKPD) Berbasis Inkuiri Pada Materi Pokok Perubahan Zat Untuk Meningkatkan Keterampilan Proses Sains (KPS) Peserta Didik Kelas VII SMP. In Seminar Nasional Biologi.

Sanjaya, W. (2006). Strategi Pembelajaran Berorientasi Standar Proses Pendidikan. Jakarta. Kencana Prenada Media Group.

Suwahru, A., Bahri, A., \& Mu'nisa, A. M. N. A. (2019). Pengembangan Lembar Kegiatan Peserta Didik (LKPD) Berbasis Keterampilan Proses Sains pada Materi Sel Kelas XI SMA. Biology Teaching and Learning, 1(1). 
Syarifah, S. (2017). Pengembangan Lembar Kerja Peserta Didik Berorientasi NIlai-Nilai Agama Islam Melalui Pendekatan Inquiri Terbimbing Materi Trigonometri. Lampung. UIN Raden Intan.

Trianto. (2007). Model-Model Pembelajaran Inovatf Berorientasi Konstruktivistik. Jakarta. Prestasi Pustaka.

\begin{tabular}{|l|l|}
\hline Asriani Askar & $\begin{array}{l}\text { Mahasiswa Jurusan Biologi, FMIPA, Universitas Negeri } \\
\text { Makassar } \\
\text { Email: } \underline{\text { Asrianiaskar18@gmail.com }}\end{array}$ \\
\hline Firdaus Daud & $\begin{array}{l}\text { Dosen Jurusan Biologi, FMIPA, Universitas Negeri } \\
\text { Makassar } \\
\text { Email: } \underline{\text { dausdaud@gmail.com }}\end{array}$ \\
\hline Syamsiah & \begin{tabular}{l} 
Dosen Jurusan Biologi, FMIPA, Universitas Negeri \\
Makassar \\
Email: $\underline{\text { syamsiah.msi@gmail.com }}$ \\
\hline
\end{tabular} \\
\hline
\end{tabular}

